\title{
Modern problems of energy efficiency programs implementation at the enterprises of mechanical engineering
}

\author{
Natalia Borisova ${ }^{1, *}$, Alexander Borisov ${ }^{2}$, and Oleg Dushko ${ }^{3}$ \\ ${ }^{1}$ The department of management and urban development and construction, Volgograd State Technical University, Volgograd, Russia \\ ${ }^{2}$ The department of economics and project management in construction, Volgograd State Technical University, Volgograd, Russia \\ ${ }^{3}$ The faculty of distance education, Volgograd State Technical University, Volgograd, Russia
}

\begin{abstract}
Russia is the one of the most wasteful countries in the world in using of fuel and energy resources. Energy-saving potential is huge enough. Thereby energy efficiency programs implementation at the enterprises of mechanical engineering is the one of priority tasks of modern economics of Russia and requires radical measures of increasing the efficiency of its implementation. The purpose of Author's search is scientific and practical research of modern problems of energy efficiency programs implementation at the enterprises of mechanical engineering. In achieving of this purpose the following tasks were solved by authors: justified relevance and necessity of implementation of energy-saving policies at the enterprises of mechanical engineering in the regions of Russia; indentified the most significant problems preventing effective implementation of energy-saving program at the enterprises in the regions of Russia; proposed possible directions solving reveal problems in sphere of energy-saving programs implementation at the enterprises in the regions of Russia. In presented research Author's collective focuses on problems of energy audit using in practice as the main instrument for working-out of energy-saving programs at the enterprises of mechanical engineering and the its subsequent implementation. The subject of Author's research is the factors defining energy-saving implementation at the enterprises of mechanical engineering, the object is the enterprises of this one. Methodological scientific and practical research is based on a complex approach with using of methods of comparative, analytical and logical analysis.
\end{abstract}

\section{Introduction}

The main reason motivating of energy-saving is the factor exhaustibility of fuel and energy resources. The idea of energy-saving arose in the end of the 20th century during the period of energy crisis most of the world's advanced countries have sought to improve the efficiency and use new alternative and renewable energy sources $[1 ; 8 ; 10 ; 12 ; 13 ; 17 ; 19]$.

In new economical facilities and for many years energy-saving is the fundamental factor of effective functioning and perspective development of many enterprises of industry in particular the enterprises of mechanical engineering of many leading countries including Russia and its regions $[7 ; 9 ; 14 ; 15 ; 16 ; 20]$.

Practical implementation of energy-saving potential is the higher priority of Russian's federal and regional economic policy because in new economical conditions every percent of fuel and energy resources saving used in production activity of the industrial enterprises in particular the enterprises of mechanical engineering may give increase of national income above $0,35 \%$ [2]. The main purpose of evergy-saving policy in mechanical engineering is cost price decline of manufactured products, increase of its competitiveness and also increase of efficiency of fuel and energy's using.

\section{Relevance and problem situation}

Today Russia is a energy-surplus country, efficiency of energy resources using at the rate is about $30 \%$ that is above $2 / 3$ of energy is wasted ineffectively. This situation worsens every year, if the measures of available potential of energy-saving's using weren't applied in our country, the onset of energy crisis would begin. In 2015 energy intensity indicators decreased by $5,61 \%$ to the level of 2008 . Despite the positive dynamics, it's very difficult to achieve the result without sound energy-saving policy specified "in energy country's policy until 2020" (decrease in energy intensity of GDP per 40\%). [2].

Multiplicative effect is necessary for energy efficiency at the expense of organizational, legal, technical, technological, economical and other measures aimed at volume reduction of used fuel and energy resources while maintaining the corresponding beneficial effect by its using. The most priority directions of energy-saving policy are industrial sector and also subsectors. Industrial enterprises are the biggest users of energy resources: they account up to $50 \%$ of energy consumption in the country. Wherein the biggest fuel and energy resources losses are observed also at

\footnotetext{
* Corresponding author: borisovani06@mail.ru
} 
industrial sectors (47\%). It attests about huge energysaving's potential. [4].

Mechanical engineering is a leading sector of Russia's economic and its main system-forming element defining industrial potential and defensive capacity's condition, sustainable functioning of all industrial sectors and filling the consumer market. Mechanical engineering is the one of the most capacious sectors of Russian industry including production every possible machinery, equipment and fittings. The etreprises's production of mechanical engineering plays a big role at scientific and technical progress's achievements implementation in all national economy's spheres of our country. The share of mechanical engineering accounts about $20 \%$ amount of issue of all Russian manufacturing industries. [4].

Analysis of energy-using's levels at mechanical engineering sector shows that the sector has significant reserves for increasing energy efficiency. At the present stage mechanical engineering is characterized by wide using of all kinds of energy at the expense of different energy resources: electric power, steam, hot water, liquid, gaseous and solid fuel. The share of electric power accounts about $24 \%$, fuel $-38 \%$, heat power $38 \%$. $10-15 \%$ of consumed energy is expended for technological purposes in mechanical engineering. The electrification's level in mechanical engineering is higher than in industry generally at that more than half the electricity is used in mechanical processes. Specific gravity of electric and technological processes exceeds $50 \%$ on some mechanical engineering enterprises. [5].

Of all consumed energy resources at the mechanical engineering enterprises are expended about $30 \%$ for technological processes and about $70 \%$ for CHPP, boiler rooms, ventilation, lighting, production of compressed air, intrafactory transport and other auxiliary needs. [5]. In its turn, moral and physical deterioration of enterpises's fixed assets (equipment and buildings) is a result of constant consumtion's increas of different kinds of energy in many mechanical engineering's enterprises of Russian regions. We give practical example to justify our conclusions:

- OJSC «Russian machines» is a large Russian diversified holding company iincluded in group «Basic element» and unifying 27 enterprises of mechanical engineering (automotive, automotive components, raliway engineering, aircraft construction, agricultural and construction machinery) in 12 Russian regions. It presented general data about value its energy resources during 2009. In 2009 total cost of energy resources of OJSC «Russian machines» was 5,2 billion rubles, to the end of 2013 their value increased to 9 billion rubles. With a rise in value of energy resources was a rise in share of energy consumption in total cost production. So in 2009 energy consumption accounted for $3,4 \%$ of total cost production and to the end of 2013 the share of energy consumption increased to $6 \%$. Eventually using of morally and physically obsolete technologies of power supply at the factories of corporation «Russian machines» (boiler equipment) was the result of constant increasing of energy consumption. According to set of the rules «Boiler settings» (set of the rules
89.13330.2012 Boiler settings) approximate lifetime of this equipment is less than 10 years. In 2013 boiler equipment's age structure at the factories of corporation «Russian machines» was introduced in the following way [6]:

$-12 \%$ of equipment is less than 10 years old;

- $14 \%$ of equipment is more than 10 years old;

- $16 \%$ of equipment is more than 20 years old;

- $47 \%$ of equipment is more than 30 years old;

- $10 \%$ of equipment is more than 40 years old.

By this way $88 \%$ of boiler equipment of OJSC «Russian machines» is exceeded standard operating life that's why energy consumption and total cost production increase.

Leading energy-saving experts affirm that in boiler rooms used at the enterprises of mechanical engineering are ineffective water treatment systems so it leads to scale formation in boilers and heat exchanger and also to decline of economy. With sedimentation of water heating boiler the boilers's efficiency falls to $60 \%$ in $2-3$ years of exploitation in bad water treatment conditions. [2].

Besides increased equipment deterioration, many mechanical engineering enterprises have high moral and physical deterioration of their industrial buildings (CHPP, boiler rooms) that also promotes rising fuel and energy resources costs, rising prime cost of engineering products and decline of competitiveness. Many regional enterprises at mechanical engineering were created during planned ecomony concerning their building's age is more than 30-40 years old. As a rule most of industrial funds of Russian regions weren't capital and current refurbished that's why it got old and worn out. Authors consider that the one of main reasons of untimely undustrial building's capital and current repairs is a change of political and economic regim in the country leading to reduction in management efficiency of their production and also to limitation of financial resources. Practice shows that industrial buildings have big physical deterioration consume more than $70 \%$ of electric power, $49,8 \%$ of natural gas, $40 \%$ of fossil energy resources [2].

Irrational using of fuel and energy recourses inflicts significant damage for mechanical engineering sector. In its turn rising energy prices, limitation of energy resources made very actual problem of energy-saving for the Russian enterprises of mechanical engineering and its regions.

\section{Research and formulation of the problems of energy efficiency programs implementation}

The legislative framework of energy-saving policy is formed beginning from 1996. So a number of legislative acts about energy-saving was accepted by the State Duma of the Russian Federation : the Federal law from 1996 №28-FL «About energy-saving», the target program «Russia's energy-saving from 1998 to 2005» from 1998 №80, «Russia's energy strategy to 2020» approved by the government order of the Russian 
Federation №1234-GO from 2003. Subprogram «Energy-saving in energy intensive sectors» of the Federal target program «Russia's energy-saving» was elaborated and recommended for practical implementation in 2000.

Energy audit or energy survey is the main source of information about the maximum losses of fuel and energy resources and the main instrument for development of energy-saving programs and their subsequent implementation on practice. Energy audit is a interconnected complex of technical, managerial, organizational, economical and other measures including information's collection and processing about using of fuel and energy resources for getting reliable data about their volume of using, indicators of energy efficiency; potential identification of energy-saving and possibilities of indicators of energy efficiency's increasing with submission of Acquired data in energy passport [2].

Energy passport is formed according to the results of energy survey which contains information about the volume and structure of production and consumption of fuel and energy resources at an enterprise, the volume and structure of their losses and also may be given recommendations about using of concrete energy-saving technologies taking into account the specifics of production activity of an investigated enterprise. [2].

From the moment of output and adoption of many regional and federal programs in energy-saving field has passed more than 15-20 years however massive development of these programs didn't happen. Energy audit experts say that top-brass of mechanical engineering's enterprises ignore the necessity of energy audit, energy-saving programs elaboration and implementation because of lack of sufficient financial resources. Also not all mechanical engineering's enterprises leaders don't recognize the necessity of energy audit for their enterprises. Such attitude of mechanical engineering's enterprises leaders to energysaving is mostly defined the share of energy consumption in total cost mechanical engineering production. And if in chemical industry the share of energy consumption may reach $40 \%$, then for mechanical engineering this number is from $6 \%$ to $15 \%$. As a result energy-saving's issues at many mechanical engineering enterprises aren't included into the list of strategic directions of their development, they are located in the introduction of only the main power engineer of an enterprise [3].

However it should be noted that some enterprises of mechanical engineering are paying active attention to energy-saving at their industry and getting sufficient economic effect from it. The bright example of energysaving policy at mechanical engineering sector is OJSC «United aircraft corporation» (OJSC «UAC»). Average cost share of aircraft enterprises OJSC «UAK» is $7 \%$ for energy resources. But relatively small indicator of main products energy intensity didn't intervene OJSC «UAK» specialists to elaborate corporate policy in energy-saving field which presents constant monitoring of energy efficiency program status of their aircraft factories, promotion of proven solutions on other enterprises of corporation, analysis of energy tariffs, staff motivation.
As a result energy-saving corporate program decreased energy consumption per unit of production significantly (all told per 40\% in 2012 and also per 30\% in 2015) and allowed saving money to 3 billion rubles every year. From 2011 to 2015 energy costs for OJSC «UAK» could increase from 3,16 to 8,2 billion rubles because of volume production increasing and increasing of tariffs for energy resources. But due to energy efficiency program implementation those costs didn't exceed 4,8 billion rubles according to estimates of OJSC «UAK» specialists [3].

Energy passport may be considered as an instrument of support for management decision-making in energysaving and increasing of mechanical engineering's energy efficiency field. The drafting of full energy passport is possible only according to results of a comprehensive energy analysis of all its sites (in particular by kinds of activity). But currently some problems are connected with energy audit organization and implementation. According to the Federal law №261-FL of the Russian Federation from 23.11.2009 «About energy-saving and increasing of energy efficiency and also about amending certain legislative acts of the Russian Federation» energy analysis isn't compulsory for enterprises with the exception of the following organizations:

- government departments and local governments endowed with the rights of legal entities;

- organizations with state participation or local government;

- organizations which the total costs of all kinds of fuel, fuel oil, thermal energy, coal, electric energy are more than 10 million rubles per annum [2].

In conclusion, many enterprises of different sectors of economy are situated in the list of organizations which must conduct energy audit so it's a positive factor. However there are some problems which exist in practice of conducting energy audit caused by accepted the Federal law №261-FL of Russian Federation from 23.11.2009. So many leading energy audit specialists consider that prescribed conditions by this document don't apply in reality. Let's learn these problems in detail.

The one of the main problems is incomprehensible form and use of energy passport. Also there are no clear and unified requirements for its formalization. No one knows how energy passport must look like, what it must contain and what instance must affirm it. Energy specialists say that the law doesn't prescribe clear rules for conducting of energy audit, it just presents some requirements and terms within which the leaders of corresponding enterprises must make energy passport. As a result specialists research energy efficiency potential of industrial enterprises according to old forms which elaborated in 2000's because of lack of clear recommendations for energy audit conducting. Experienced energy audit specialists think that another important problem is almost impossible to find a competent auditor. In current market conditions there are more than energy audit organizations function emerging during popularization of this topic in our country. But 
only hundreds of existing energy audit organizations match self-regulating organizations in energy audit field. The current problem is that the standard course duration about energy auditing fundamentals lasts only 72 hours. It's impossible to teach a future energy audit specialist during this time. As a result less than 100 energy audit companies in Russia can offer qualified services. For this reason in rare happenings energy efficiency analysis is conducted economically competently [1].

Also very important problem is that there is no unified methodology about energy audit conducting at the enterprises of mechanical engineering in Russia wherein its algorithm would be prescribed clearly. No methodology serving as a standard for comparison analysis results of investigated enterprise. However we need to remember that energy audit conducting will give nothing if don't invest in energy-saving technologies for the enterprises of mechanical engineering [1]. It's necessary to get experience of foreign companies offering their own modern energy-saving technologies and clear methods about energy audit conducting for the enterprises of mechanical engineering $[7 ; 9 ; 15 ; 16 ; 18]$

It should be noted that experience of foreign countries prove that energy audit in our country needs governmental support within the framework of energysaving of mechanical engineering enterprises as complex process. For example, in Finland general directions of energy audit work come from the Ministry of Labor and Finland's economy. State Center for Economics, Ecology and Transport provides subsidies for an enterprise in the end of work when an auditor made a report and checked the quality of work with a customer. There are different models of energy audit for every sphere of a client's enterprise. If in Russia energy audit is given to the business and self-regulating organizations, in Finland the government is interested at the energy audit results because it allocates funds for expertise of projects. Besides Finnish auditors take a report about energy audit, Russian auditors take an energy passport. $[1 ; 11]$.

According to the experience of Finland energy audit is a complex approach during the analysis of an enterprise, it's not just solution of technical tasks but also economic tasks and also tasks about production development based on the introduction of specialized technologies, preservation of the environment -reduction of emissions and negative impact on it. For Russia Finland's experience may be estimated first and foremost that they have data of comparison of energysaving potential which theoretically grounded by energy auditors at technical report and actual potential of energy-saving realized those years in their country. The accuracy of theoretical forecasts of Finnish energy auditors is about $70 \%$. [1; 11].

At the present time energy audit secured by law and its official status is confirmed formally. But on practice concept of energy audit exists only in law, its real function is reduced to formality and ambiguity.

In this way on the surface are the key problems in energy-saving programs implementation for the enterprises of mechanical engineering through energy audit caused by the Federal law №261-FL from
23.11.2009 on practice. We formulate them briefly and clearly:

- lack of clear rules and any budget for energysaving programs implementation prescribed by law;

- lack of unified form of energy passport and clear requirements about its formalization for the mechanical engineering enterprises;

- deficiency of competent energy audit specialists able to correctly identify reserves on possible saving of energy resources for the enterprises of mechanical engineering;

- lack of unified and clear methods for energy audit conducting for the enterprises of mechanical engineering at the federal and regional levels;

- lack of investment projects about elaboration of energy-saving technology for mechanical engineering enterprises;

- lack of regional service, centers for energy audit organization and implementation at the enterprises of mechanical engineering.

At the moment only some Russian mechanical engineering enterprises conduct energy audit, elaborate and implement energy-saving measures. And also some enterprises of mechanical engineering try to decide their problems about energy efficiency by way of elaboration of energy-saving programs according to the energy audit results which collide with similar problems described above by the authors. We give practical example to justify our conclusions.

So described above by the authors OJSC «Russian machines» started to solve its problems in a complex manner about energy efficiency in several stages because of constant increasing of energy consumption and its share in prime cost of engineering products and also elevated morally and physically deterioration of its fixed assets in particular equipment in 2014. The basic stage of problem solving about energy efficiency was energy audit within the framework of the following ways: conducted energy audit for all 27 enterprises; elaborated energy efficiency programs; the corporate enterprises are provided with registered energy passports; implemented measures within the framework of approved programs and energy efficiency increasing through the conclusion of energy service contracts. But the leaders of OJSC «Russian machines» collided with the following problems during energy audit [6]:

1. The expertise process of energy passports isn't worked out and formalized finally at self-regulating organizations with subsequent registration in the Ministry of energy. Formed energy passports aren't registered that doesn't allow to have feedback for improvement of the methodology of energy audit during work at other enterprises;

2. The search of competent auditors is complicated because of lack of such specialists with profile basic education and experience. With a high demand for staff of this direction supply of personnel is very low both in quality and quantity;

3. No methodology for energy audit so it complicates starting phase of activity. 
The following stage of problem solving about energy efficiency of OJSC «Russian machines» will be a transition to professional management of energy infrastructure for reduction of costs on it and purchased energy resources of corporate enterprises and also elaboration of energy management optimization program with accumulation of experience and increasing of business capitalization to gain access to cheap financing. The final stage of problem solving about energy efficiency in a complex manner of OJSC «Russian machines» will become the creation of its own generation based on energy settings working in the mode of combined generation of electric and thermal energy by building a mini-cogeneration plant at the corporate enterprises to provide baseline load coverage. As a result synergy of all described directions presupposes achieving the maximum energy-saving effect, reduction in cost and increasing of competitiveness of production of OJSC «Russian machines». [6].

\section{The basic directions of the decision of the put problems}

In our country attitude to using of energy resources, fuel and energy resources should be called wasteful and this is more a tradition than a temporary. Unfortunately economy of all types of energy is represented as the requirement of supervisory authorities for us. At the same time the bases of careful attitude to all types of energy are laid down in childhood abroad [8;12].

We agree with the opinion of energy audit experts that it's necessary to live tens of years in Russia to change consciousness of fellow citizens and attitude to the concept of «economical consumption of energy resources». Now our mindset makes us act quite differently even if law is called up to limit the rights traditionally. Also many energy audit experts think that creation of the federal and regional coordination centers is necessary to improve the system of work organization on energy audit. Representatives of executive and legislative branches, energy public organizations, selfregulating organizations and various political parties should be included in these centers.

In this way according to the leading energy audit expert's opinion and their recommendations we formulated the basic directions about energy efficiency program implementation of the regional enterprises of mechanical engineering on practice:

- creation of the federal and regional coordination centers which organize work on integrated energy audit for the enterprises of mechanical engineering according to which elaborate priority measures for energy-saving and its practical implementation;

- elaboration of unified methodology on the federal level and also clear mothodologies of energy audit, energy-saving technologies, various models of energy audit conducting;

- elaboration unified form of energy passport on the federal level for the enterprises of mechanical engineering and also elaboration of clear requrements to its formalization;
- financial governmental support for energy audit conducting of regional enterprises of mechanical engineering;

- re-attestation of specialists of energy audit companies with the aim of the compliance of their competence with the provided energy audit services for the enterprises of mechanical engineering and other industrial sectors;

- change of criteria (more stringent) of the licensing of energy audit companies provided energy audit services for the enterprises of mechanical engineering and other industrial sectors;

- public and private investment projects on development of energy-saving technologies for the enterprises of mechanical engineering;

- change of the awareness of necessity energy-saving meausres implementaion by way of intensification of outreach work on energy-saving by radio, television, mass media for the leaders of the mechanical engineering enterprises and population in general.

\section{Conclusion}

Energy-saving has to become the priority direction of activity for the enterprises of mechanical engineering at the moment. Active energy-saving policy is a necessary condition of increasing of production competitiveness and acceleration of scientific and technical progress in mechanical engineering industrial sectors. Also energysaving will allow contributing to improvement to the environment.

Interest and involvement of all participants in production including executive authorities of each region of Russia are necessary condition for successful energysaving policy implementation in mechanical engineering sector. It's possible to increase the availability of means of accounting and automatic regulation of production processes and using of fuel and energy resources and also more efficient to keep records and control of energy consumption only when maximum mobilization of used energy resources and optimal return of subjects of energy-saving policy will be implemented.

\section{References}

1. N. Borisova, A. Borisov, and E.Viprickaya, Economy and business, 12-3, 412 (2015)

2. V. Bushuev, Energy policy, 1, 3 (2014)

3. M. Dubinsky, Energy-saving, 3, 32 (2010)

4. E. Korosteleva, Young scientist, 1(8), 140 (2011)

5. N. Lazutkina, Modern problems of science and education, 2, (2013)

6. E. Razumny, Statements, 4179 (2016)

7. R. Simanjuntak, P. Dupuis, L. Canale, N. Sinisuka, \& G. Zissis, IEEE Industry Application Society Annual Meeting. (2014)

8. X. Zhao, H. Li, L. Wu, \& Y. Qi, Energy Policy, 66, $170,(2014)$ 
9. V. Blass, C. Corbett, M. Delmas, \& S. Muthulingam, Energy, 65, 560 (2014)

10. A. Sclafani, ASME 2010 4th International Conference on Energy Sustainability, 1. (2010)

11. L. Okkonen, \& N. Suhonen, Energy Policy, 38, 3443 (2010)

12. T. Fleiter, J. Schleich, \& P. Ravivanpong, Energy Policy, 51, 863 (2012)

13. S. G.Al-Ghamdi, \& M. M. Bilec, Environmental Science \& Technology, 49, 4048 (2015)

14. P. Sun, \& P. Nie, Renewable Energy, 74, 255 (2015).

15. M. Marques, \& R. Neves-Silva, Journal of Cleaner Production, 88, 105 (2015)

16. A. Al-Mofleh, S. Taib, \& H. Al-Gulman, 2008 5th International Symposium on Mechatronics and Its Applications. (2008)

17. W. Zhang, S. Liu, N. Li, H. Xie, \& X. Li, Renewable and Sustainable Energy Reviews, 49, 395 (2015)

18. A. G. Engelen, \& J. S. Collins, 2010 43rd Hawaii International Conference on System Sciences. (2010).

19. M. Abdel-Wahab, \& D. Ali, International Journal of Green Energy, 10(2), 137 (2013)

20. A. Mansikkasalo, \& P. Soderholm, 2012 9th International Conference on the European Energy Market (2012) 